\title{
Effect of Incorporation of Granite and Marble Rejects in Clay Brick Products: Physico-Mechanical Analysis
}

\author{
S. Dhanapandian ${ }^{a, *}$, C. Manoharan ${ }^{a}$, T. Ramkumar $^{b}$, B. Gnanavel $^{a}$, \\ P. SUtharsan ${ }^{a}$ AND M. Shanthi ${ }^{c}$ \\ ${ }^{a}$ Department of Physics, Annamalai University, Annamalainagar, India \\ ${ }^{b}$ Department of Earth Sciences, Annamalai University, Annamalainagar, India \\ ${ }^{c}$ FEAT, Annamalai University, Annamalainagar, India
}

(Received February 23, 2010; in fianl form May 13, 2010)

\begin{abstract}
The objective of this work is to characterize and evaluate the effect of incorporation of granite and marble rejects on the properties and microstructure development of three different clay materials used to fabricate brick materials in the brick industry. The raw materials are characterized with respect to their chemical composition by X-ray fluorescence, particle size distribution and mineralogical composition by X-ray diffraction and plasticity. Compositions have been prepared with additions of 0,10,20,30,40 and $50 \mathrm{wt} \%$ reject in three different clay material from Tamilnadu State, India, and fired at temperatures from 500 to $900{ }^{\circ} \mathrm{C}$ in laboratory furnace. The behaviour of mixtures containing $80 \mathrm{wt} \%$ clay material $+20 \mathrm{wt} \%$ reject is discussed in detail. The technological properties of briquette specimens such as flexural rupture strength, water absorption, porosity and bulk density were determined. The microstructure of the fired briquette specimens were observed by scanning electron microscopy with energy dispersive X-ray spectrometry, Mössbauer spectroscopy. The results of the above studies show that incorporations of granite and marble rejects up to $50 \mathrm{wt} \%$ is potential to the industrial clay brick products, with no major sacrifice on the properties of the final product, anticipating no costly modifications in the industrial production line.
\end{abstract}

PACS numbers: 81.70.Bt, 28.41.Kw, 76.80.+Y, 61.05.C-

\section{Introduction}

At the time of independence, India had a population of about 330 million and 65 million houses to accommodate them. Since then it has been added on an average of 2 million houses per year. With the increase in population, there has been a steady increase in housing requirement. India needs today about 25 million houses, whereas the building materials available at present are far less than the present demand. This fact is enough to alert the people living in India to the need for exploring technically and financially feasible building materials including alternate raw materials for building. Thus, converting industrial and agro based by products as possible construction materials by themselves or in combination needs to be seriously pursued.

In the small-scale sector, there are about 50,000 tiles and brick industries in India, employing around 8 million people. Most of these industries are rural based, providing employment to rural people. These industries are the major contributors towards housing in rural as

\footnotetext{
* corresponding author; e-mail: dhanahockey@yahoo.co.in
}

well as urban areas. These industries entirely depend on the clay from agricultural fields. About 50,000 acres of $60 \mathrm{~cm}$ deep fertile top soil is removed for making bricks and tiles. From the ecological point of view and in a country like India, where agriculture is the backbone for their economic growth, one cannot afford to let reduced crop area for cultivation.

One of the major problems in tile and brick industries is the paucity of good quality clay. These industries, having excavated the clay for centuries, have already exhausted the good quality clay which are incidentally essential for agricultural use also. Because of the paucity of clay and other related problems many industries either have already been closed or they are virtually under the threat of closure.

The fact that enormous quantity of various kinds of waste that are generated in India possesses similar characteristics that are needed for building materials like bricks, tiles etc., but one need not have to worry about the paucity of raw materials. To augment the availability of existing raw materials, exploitation of the solid waste recycle technology can be usefully adopted for making roofing tiles, bricks and other building materials. Otherwise, one has to spend a lot of money and energy towards 
the management of dumping yards of these wastes. So, it is important to find out an appropriate cost and energy efficient technology for using these materials in the manufacture of bricks, tiles and other building and ceramic products.

Tamilnadu state boasts of good deposits of granite and marble. There are more than 1200 granite and marble processing industries in the small scale sector apart from about 650 medium processing units located in Salem, Madurai, Virudhunagar, Hosur, Pudukkottai and Kanchipuram regions. Figure 1 shows the location map of clay materials and rejects [Salem (SLM), Namakkal (NKL) and Erode (EDE)] districts.

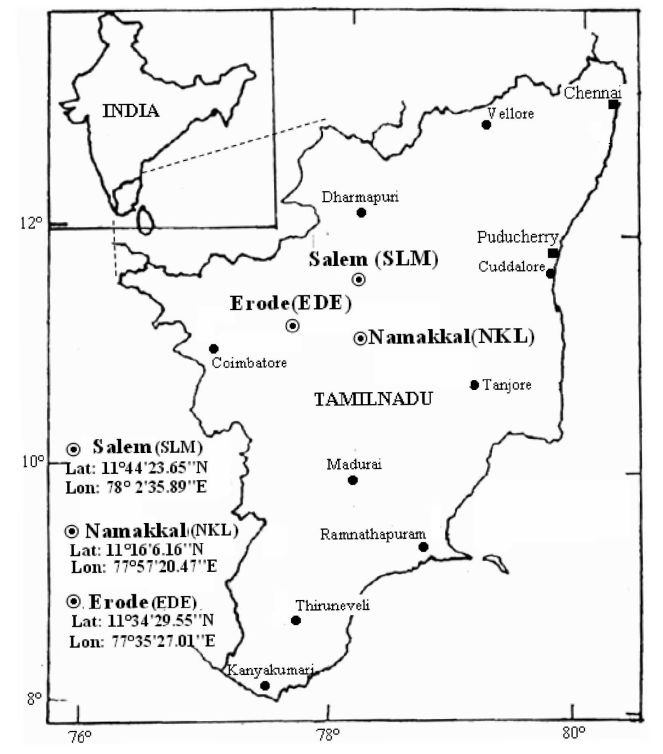

Fig. 1. The location map of clay material and rejects investigated [Salem (SLM), Namakkal (NKL) and Erode (EDE)].

The ornamental stone industries have sawing and polishing of rock blocks as one of the main activities, which can cause serious damages in the environment, such as soil and underground water contamination and it has been blamed as the reason for severe lung diseases among local people, if not efficiently treated before disposal $[1,2]$. Granite and marble rejects are becoming a worrying factor for industry owners and environmentalists alike. A growing amount of rejected mud is continuously discarded into riverbeds and lagoons, eventually leading to environmental degradation. Granite and marble are basically composed of $\mathrm{SiO}_{2}, \mathrm{Al}_{2} \mathrm{O}_{3}, \mathrm{Fe}_{2} \mathrm{O}_{3}$ and $\mathrm{CaO}[3,4]$. The corresponding rejects can be classified as fluxes, as they have the potential to act as glassy phase formers during the sintering process, improving the sinterability of the clay material. The effect of addition of granite and marble rejects in clay materials has already been investigated [5-8], and it is observed that the final properties of the fired products do not change drastically. It has also been shown that higher contents of granite and marble rejects can be used to enhance the processing of clay products [9].

Therefore, the objective of the present work is to study the possibility to incorporate granite and marble rejects in clay brick products without degrading their properties.

\section{Experimental procedure}

The basic raw materials used in this investigation are three different local clay materials already in use for the production of bricks in the industries, with a plasticity index of 19.1, 21.9, and 19.2\% from Salem, Namakkal, and Erode Districts respectively, and marble rejects have been obtained when the rocks are sawed in blocks or slices from Salem District, Tamilnadu state, India. The sample from Salem is named as SLM, Namakkal as NKL, and Erode as EDE. Both the raw materials were initially dried at $110^{\circ} \mathrm{C}$ before mixing and they were submitted to characterization including chemical composition (X-ray fluorescence, XRF, Philips PW-1400), mineralogical composition (X-ray diffraction, XRD, Philips PW-1710 powder diffractometer with $\mathrm{Cu} K_{\alpha}$ radiation). XRD patterns were obtained by step scanning from 20 to $70^{\circ} 2 \theta$ with a count for $0.5 \mathrm{~s} /$ step, exploration speed of $7^{\circ} / \mathrm{min}$ and $40 \mathrm{kV}$ and $40 \mathrm{~mA}$ in the X-ray tube and particle size distribution (HORIBA LA-910). The Atterberg limits of compositions constituted by clay materials and granite and marble rejects were determined. Selected mixtures containing $0,10,20,30,40$ and $50 \mathrm{wt} \%$ of reject were prepared and homogenized for $4 \mathrm{~h}[10]$ in planetary mill with alumina grinding balls. In the laboratory scale studies, samples composed by clay material and rejects, $5.0 \times 2.5 \times 2.5 \mathrm{~cm}^{3}$, were extruded and fired to 500,600, 700,800 and $900^{\circ} \mathrm{C}$ in an oxidizing atmosphere for $2 \mathrm{~h}$ with a heating rate of $10^{\circ} \mathrm{C} / \mathrm{min}$.

After firing at selected temperatures, the flexural rupture strength of the sintered samples were determined at three-point bending tests (Shimadzu Autograph) with a constant cross-head speed of $0.5 \mathrm{~mm} / \mathrm{min}$. Water absorption, porosity and bulk density were determined by using the Archimedes water displacement method. Microstructure characterization of fracture surfaces of mixtures containing $80 \mathrm{wt} \%$ clay material and $20 \mathrm{wt} \%$ reject sintered at $900{ }^{\circ} \mathrm{C}$ were observed by scanning electron microscopy (JEOL JSM-5610, at $25 \mathrm{kV}$, after gold coating) and qualitative energy dispersive spectrometry (EDS) is used to identify the various phases observed. ${ }^{57} \mathrm{Fe}$ Mössbauer spectra were recorded at room temperature (RT) in transmission mode with a conventional constant acceleration spectrometer equipped with a ${ }^{57} \mathrm{Co}(\mathrm{Rh})$ source. Absorbers were prepared from powdered sample with a thickness of $100 \pm 10 \mathrm{mg} / \mathrm{cm}^{2}$ using a PMM compression holder. The spectra were computer-fitted to a sum of Lorentzian lines by applying the constraints of equal line width and area for the two peaks of each doublet and equal line width and areas in the ratio $3: 2: 1: 2: 3$ for the six peaks of sextets. Isomer shifts $(\delta)$ were referred to the centroid of the spectrum of $\alpha$-Fe at RT. The relative 
concentration of the different Fe species was calculated from the spectral area ratio assuming that the $f$-factor (probability of the Mössbauer effect) is the same in all the implicated species.

\section{Results and discussion}

The chemical composition of three different clay materials collected from the brick industry available in SLM, NKL, and EDE districts, and the granite and marble reject collected from companies located in SLM district are provided in Table I. It is observed from Table I that clay material of SLM, NKL, and EDE contains $\mathrm{SiO}_{2}$ 69-68-70 wt\% and $\mathrm{Al}_{2} \mathrm{O}_{3}$ 12-10-12 wt\%. The clays also contain $\mathrm{CaO}$ 4-3-2 wt\% and $\mathrm{Fe}_{2} \mathrm{O}_{3}$ 2-2-2 wt\%. X-ray diffraction and EDS studies of the above clays show the presence of quartz as predominant. Therefore, it is confirmed that the above clays are quartzitic in nature [11]. Clays also show the presence of minor contents of $\mathrm{Mg}, \mathrm{K}$, $\mathrm{Ti}$ and $\mathrm{Na}$ oxides. The loss on ignition (5 and $7 \mathrm{wt} \%$ ) is within the usual range for clay materials, and is most likely associated with volatile components and organic matter [9]. Segadaes et al. [3] and Monteiro et al. [12] have studied the effect of addition of marble and granite rejects to clay products and have reported that significant amount of iron oxide $\left(\mathrm{Fe}_{2} \mathrm{O}_{3}\right)$ in clays and rejects is responsible for the reddish colour of the clay products after firing. It is observed that in terms of oxides, the reject material is formed basically by $\mathrm{SiO}_{2}, \mathrm{Al}_{2} \mathrm{O}_{3}$ and $\mathrm{CaO}$, with small amounts of $\mathrm{Fe}_{2} \mathrm{O}_{3}, \mathrm{MgO}, \mathrm{K}_{2} \mathrm{O}$, and $\mathrm{Na}_{2} \mathrm{O}$. The loss on ignition results from the decomposition of calcite and dolomite. XRD pattern of reject material shows the presence of a few peaks corresponding to calcite and dolomite. The presence of significant amount of alkaline earth oxide content, particularly $\mathrm{CaO}$ and $\mathrm{K}_{2} \mathrm{O}$, will act as a fluxing agent during the sintering process. Figure 2 represents the XRD patterns of the three different clay materials and the reject material. It can be noted that the three different clay materials are mainly constituted by quartz and minor amounts of albite and anorthite. The reject contains quartz as major constituent and minor amounts of albite, anorthite, calcite, dolomite and hematite. The presence of iron oxides in the clay materials could not be detected through X-ray diffraction analysis. Wagner et al. [13, 14] have reported that the presence of iron oxides in clays cannot be detected by X-ray diffraction analysis, because of its low concentration and poor crystalline. The crystalline phases identified by X-ray diffraction agree with the results obtained by XRF (Table I).

Figure 3 represents the particle size distribution of three different clay materials and the granite and marble rejects. It can be observed that clay material collected from SLM, NKL and EDE has a percentage of clay minerals, i.e., that with particle size $<2 \mu \mathrm{m}$, of 43,49 and $45 \mathrm{wt} \%$. The intermediate fractions, associated with silt $2-20 \mu \mathrm{m}$ are of 26,23 and $24 \mathrm{wt} \%$. The fine sand of the clay materials, $20-200 \mu \mathrm{m}$, are of 25,24 and $26 \mathrm{wt} \%$.

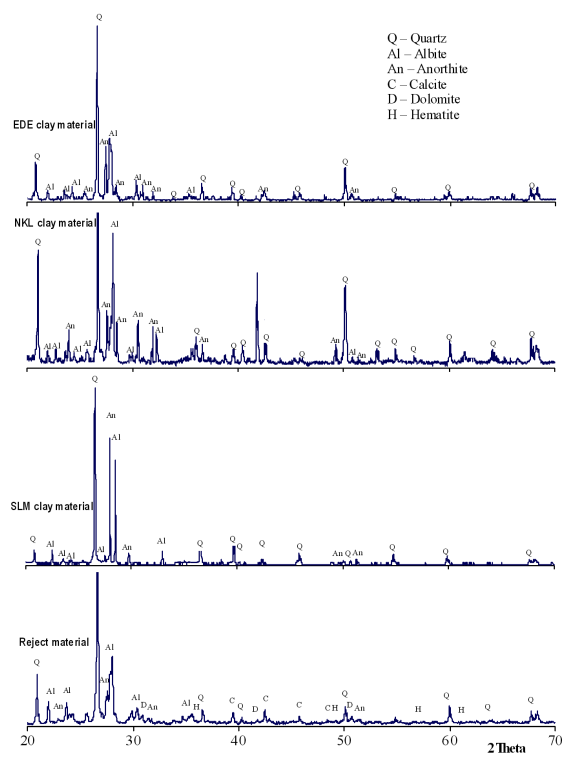

Fig. 2. X-ray diffraction pattern of the raw materials.

TABLE I

Chemical composition of the raw materials, as determined by XRF (wt\%).

\begin{tabular}{c|c|c|c|c}
\hline \hline $\begin{array}{c}\text { Chemical } \\
\text { constituent }\end{array}$ & $\begin{array}{c}\text { SLM clay } \\
\text { material }\end{array}$ & $\begin{array}{c}\text { NKL clay } \\
\text { material }\end{array}$ & $\begin{array}{c}\text { EDE clay } \\
\text { material }\end{array}$ & $\begin{array}{c}\text { Reject } \\
\text { material }\end{array}$ \\
\hline $\mathrm{SiO}_{2}$ & 69.83 & 68.76 & 70.18 & 66.04 \\
$\mathrm{Al}_{2} \mathrm{O}_{3}$ & 12.24 & 10.20 & 12.92 & 14.25 \\
$\mathrm{Fe}_{2} \mathrm{O}_{3}$ & 2.77 & 2.78 & 2.72 & 2.83 \\
$\mathrm{TiO}_{2}$ & 0.08 & 0.02 & 0.05 & 0.02 \\
$\mathrm{CaO}$ & 4.20 & 3.36 & 2.80 & 4.48 \\
$\mathrm{MgO}$ & 2.22 & 2.40 & 2.20 & 2.42 \\
$\mathrm{~K}_{2} \mathrm{O}$ & 0.72 & 1.25 & 1.85 & 1.78 \\
$\mathrm{Na}_{2} \mathrm{O}$ & 1.14 & 0.67 & 0.76 & 1.08 \\
$\mathrm{MnO} \mathrm{O}$ & 0.01 & 0.05 & 0.01 & 0.02 \\
$\mathrm{P}_{2} \mathrm{O}_{5}$ & 0.02 & 0.03 & 0.03 & 0.01 \\
$\mathrm{H}_{2} \mathrm{O}^{-}$ & 1.32 & 2.63 & 1.22 & 2.13 \\
$\mathrm{LoI}^{a}$ & 5.52 & 7.98 & 5.24 & 5.10 \\
\hline
\end{tabular}

${ }^{a} \mathrm{LoI}$ - loss on ignition

The coarser fraction of the above three different clay materials, i.e. with the particle size $>200 \mu \mathrm{m}$, corresponds to 6,4 and $5 \mathrm{wt} \%$, respectively. In the case of granite and marble reject, it is noticed that particle size in between $2-20 \mu \mathrm{m}$, associated with silt, is of $80 \mathrm{wt} \%$. The presence of fine sand, 20-200 $\mu \mathrm{m}$, is of $20 \mathrm{wt} \%$. Vieira et al. [15] have studied the characteristics of clays and properties of building ceramics in the state of Rio de Janeiro, Brazil and reported that the clay fraction is associated with very fine clay minerals that are mainly responsible for the plasticity of clay materials. According to Fig. 3, clay materials collected from SLM, NKL, and EDE display 
the required amount of clay fraction 43, 49 and $45 \mathrm{wt} \%$, respectively, is the reason for the sufficient amount of plasticity. One may also conclude that the silt fraction present in the clay mixtures $(26,23$ and $24 \mathrm{wt} \%$ ) and the highest amount ( $80 \mathrm{wt} \%)$ in the granite and marble reject also helps the development of plasticity. Plasticity is an important parameter for the production of constructional clay brick, because, brick industry mainly uses extrusion shaping and therefore insufficient plasticity creates extrusion failures and heterogeneities in clay body and this causes lower mechanical properties [16]. The plasticity index of clay is defined as the difference in water content between the liquid and plastic limits. The liquid limit is the relatively high water content at which the clay changes from a liquid to a plastic state, and the plasticity limit is the relatively low water content at which clay changes from a plastic to a solid state. Plasticity index refers to the resistant force to deformation and gives a better appraisal of the behaviour of plastic substance. The plasticity indices of three different clay materials and the effect of granite and marble reject are shown in Fig. 4.

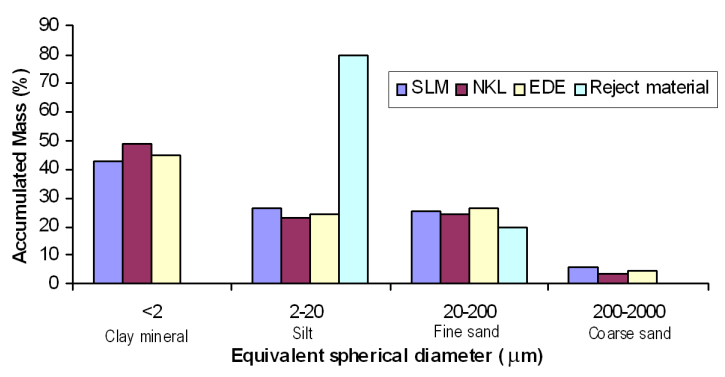

Fig. 3. Particle size distribution of the raw materials.

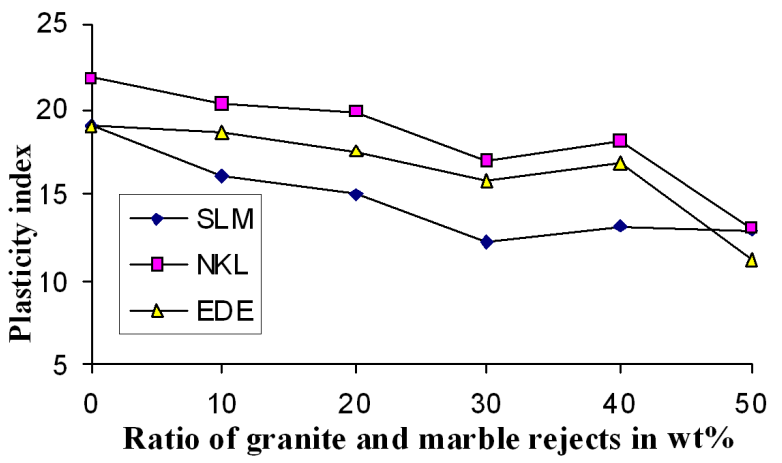

Fig. 4. Plasticity indices of SLM, NKL, and EDE clay materials as a function of reject content.

According to Vieira et al. [15], for practical purposes the plasticity index must be above $10 \%$ and if it is $<10 \%$, it is not appropriate for the production of clay-based materials due to the risk problems during the extrusion process. From Fig. 4, it is noticed that when granite and marble reject are mixed with raw clay materials of SLM,
NKL and EDE at 0, 10, 20, 30, 40 and $50 \mathrm{wt} \%$, the plasticity index values gradually decrease, but not less than $10 \%$. From this result, it is understood that the raw clay materials collected from the brick industry located in SLM, NKL, and EDE districts are suitable for producing granite and marble reject mixed clay bricks by extrusion process.

Iron is generally present in unpurified clays in concentrations of several percent. During firing, iron undergoes characteristic changes on its chemical and physical state, depending on the kiln atmosphere and on the maximum temperature reached. These changes can be followed by the Mössbauer spectroscopy [17-19]. For the present investigation, room temperature Mössbauer spectra have been recorded for fired industrial brick as well as reformulated briquette specimen sintered at $900{ }^{\circ} \mathrm{C}$ (Fig. 5). The recorded spectra were used to estimate the original firing temperature of the industrial bricks and to ascertain any micro structural changes take place on iron components by mixing granite and marble reject into raw clay materials. Table II gives the Mössbauer parameters and relative concentrations of the different species calculated from the fitted spectra.
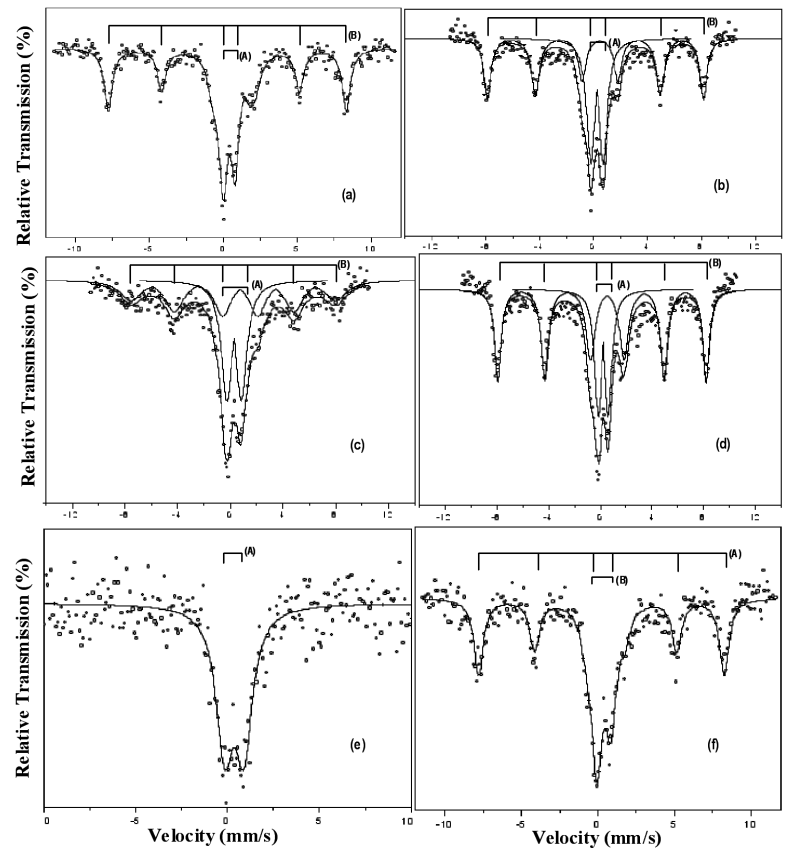

Fig. 5. Room temperature Mössbauer spectra of (a) industrial brick of SLM, (b) clay material of SLM $+20 \mathrm{wt} \%$ reject sintered at $900{ }^{\circ} \mathrm{C}$, (c) industrial brick of NKL, (d) clay material of NKL $+20 \mathrm{wt} \%$ reject sintered at $900^{\circ} \mathrm{C}$, (e) industrial brick of EDE, (f) clay material of $\mathrm{EDE}+20 \mathrm{wt} \%$ reject sintered at $900^{\circ} \mathrm{C}$. 
TABLE II

Room temperature Mössbauer parameters.

\begin{tabular}{c|c|c|c|c|c|c}
\hline \hline & $\begin{array}{c}\text { SLM } \\
\text { industrial } \\
\text { brick }\end{array}$ & $\begin{array}{c}\text { Reformulated } \\
\text { briquette } \\
\text { specimen } \\
\text { of SLM }\end{array}$ & $\begin{array}{c}\text { NKL } \\
\text { industrial } \\
\text { brick }\end{array}$ & $\begin{array}{c}\text { Reformulated } \\
\text { briquette } \\
\text { specimen } \\
\text { of NKL }\end{array}$ & $\begin{array}{c}\text { EDE } \\
\text { industrial } \\
\text { brick }\end{array}$ & $\begin{array}{c}\text { Reformulated } \\
\text { briquette } \\
\text { specimen } \\
\text { of EDE }\end{array}$ \\
\hline $\begin{array}{c}\text { Double - A } \\
\delta[\mathrm{mm} / \mathrm{s}]\end{array}$ & 0.412 & 0.310 & 0.300 & 0.340 & 0.374 & 0.386 \\
$\Delta[\mathrm{mm} / \mathrm{s}]$ & 0.411 & 0.900 & 1.070 & 0.890 & 1.205 & 0.927 \\
$I_{\mathrm{rel}}[\%]$ & 45.2 & 45.7 & 55 & 34 & 100 & 47.1 \\
Sextet - B & & 0.350 & 0.430 & 0.350 & - & 0.366 \\
$\delta[\mathrm{mm} / \mathrm{s}]$ & 0.382 & -0.260 & 0.130 & -0.240 & - & -0.275 \\
$\Delta[\mathrm{mm} / \mathrm{s}]$ & -0.225 & 50.8 & 49.8 & 51.0 & - & 50.86 \\
$H(T)$ & 50.5 & 54.3 & 45 & 66 & - & 52.9 \\
$I_{\mathrm{rel}}[\%]$ & 54.8 & 5
\end{tabular}

$\delta$ - isomer shift, relative to $\alpha$-Fe, $\Delta$ - electric quadrupole splitting,

$H(T)$ - magnetic hyperfine field in $\mathrm{T}, I_{\mathrm{rel}}$ - relative spectral area

The Mössbauer spectra of both SLM and NKL industrial bricks and clay material $+20 \mathrm{wt} \%$ reject mixed briquette specimens sintered at $900{ }^{\circ} \mathrm{C}$ show the presence of a characteristic paramagnetic doublet in the central part of the spectrum and a magnetic component with rather broad lines. Spectra are best fitted to a double (A) and a sextet for SLM and NKL industrial bricks and reformulated to a doublet $(\mathrm{A})$ in the case of EDE industrial brick and a doublet (A) and sextet (B) in the case of reformulated briquette specimen. The presences of only $\mathrm{Fe}^{3+}$ species in the spectra indicate that industrial bricks and reformulated briquette specimens are fired in an oxidizing atmosphere. The parameters of the doublet correspond to an $\mathrm{Fe}^{3+}$ octahedral coordination and allow the doublet assignment either to substitutional $\mathrm{Fe}^{3+}$ in the clay mineral structure or to superparamagnetic ferric oxides [20, 21]. Electric quadrupole splitting values of the doublet allow us to infer a rough estimation of the firing temperatures as above $800^{\circ} \mathrm{C}$, in between 700 and $800^{\circ} \mathrm{C}$ and around $600^{\circ} \mathrm{C}$ for the industrial bricks collected from SLM, NKL, and EDE, respectively. From its magnetic hyperfine parameters (Table II), sextet B can be identified as hematite $\left(\alpha-\mathrm{Fe}_{2} \mathrm{O}_{3}\right)$. The low magnetic hyperfine field value and line broadening of sextet $B$ in the Namakkal industrial brick is attributed to the presence of substituted forms of hematite (Al-substituted hematite, for example, $\alpha-\left(\mathrm{Fe}_{1-x} \mathrm{Al}_{x}\right)_{2} \mathrm{O}_{3}$ (Brown, 1979). The difference observed in the room temperature Mössbauer spectra of Erode industrial brick and clay material +20 wt $\%$ reject mixed briquette specimen sintered at $900{ }^{\circ} \mathrm{C}$ are mainly due to the difference in firing temperatures of the materials.

Finally, it is concluded that by mixing granite and marble rejects into raw clay materials of SLM, NKL and EDE, one does not observe a new form of iron components at higher temperature. The identical Mössbauer spectra of industrial bricks and reformulated briquette specimens reveal that the presence of iron components on clay materials and rejects are the same and similar transformations occur at higher temperatures.
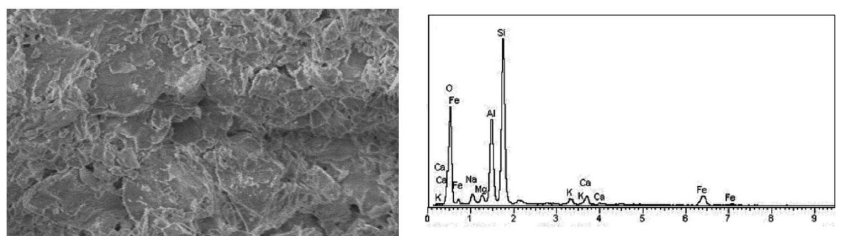

$\mathrm{EHT}=5.00 \mathrm{kV}$ WD $=15 \mathrm{~mm}$

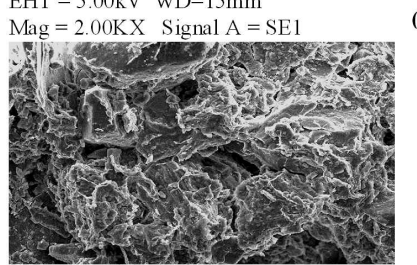

(a)

$\mathrm{EHT}=5.00 \mathrm{kV} \quad \mathrm{WD}=15 \mathrm{~mm}$

Mag $=2.00 \mathrm{KX} \quad$ Signal $\mathrm{A}=\mathrm{SE} 1$
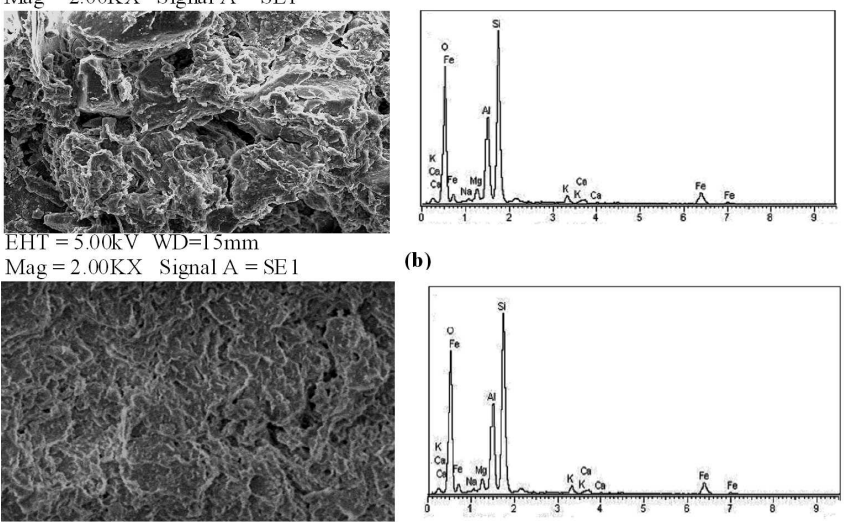

(b)

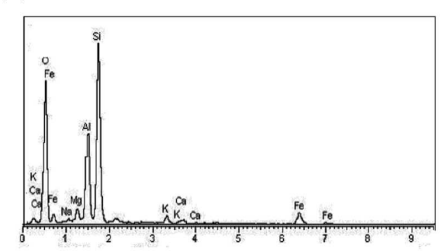

$\mathrm{EHT}=5.00 \mathrm{kV} \quad \mathrm{WD}=15 \mathrm{~mm}$

$\mathrm{Mag}=2.00 \mathrm{KX} \quad$ Signal $\mathrm{A}=\mathrm{SE} 1$

(c)

Fig. 6. SEM-EDS micrographs of the fracture surfaces of clay briquette specimens of (a) SLM, (b) NKL, and (c) EDE, sintered at $900{ }^{\circ} \mathrm{C}$ in the laboratory.

SEM with EDS studies have been performed in order to get a better understanding of the morphology of the microstructure development of reformulated briquette specimens and to identify various phases present in the materials. SEM with EDS images of fracture sur- 

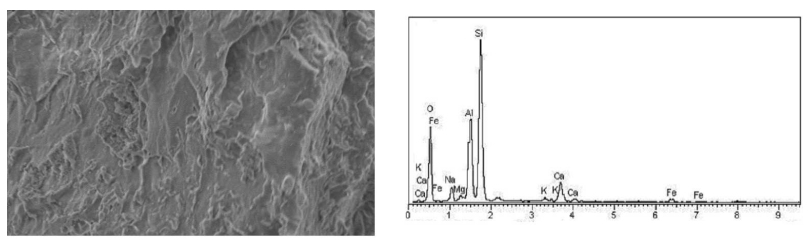

$\mathrm{EHT}=5.00 \mathrm{kV} \quad$ WD $=15 \mathrm{~mm}$
$\mathrm{Mag}=2.00 \mathrm{KX} \quad$ Signal A $=$ S

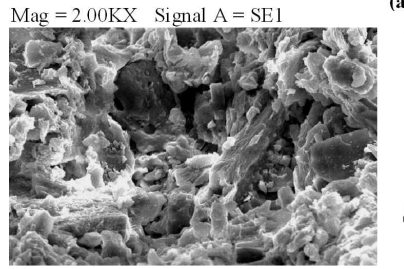

(a)

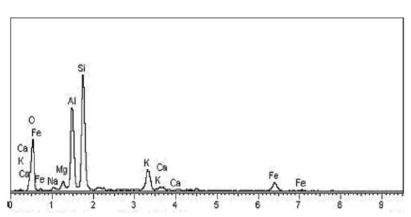

$\mathrm{EHT}=5.00 \mathrm{kV} \quad \mathrm{WD}=15 \mathrm{~mm}$

$\mathrm{Mag}=2.00 \mathrm{~K}$ X Signi $\mathrm{A}=\mathrm{SE}$

$\mathrm{X}$

(b)
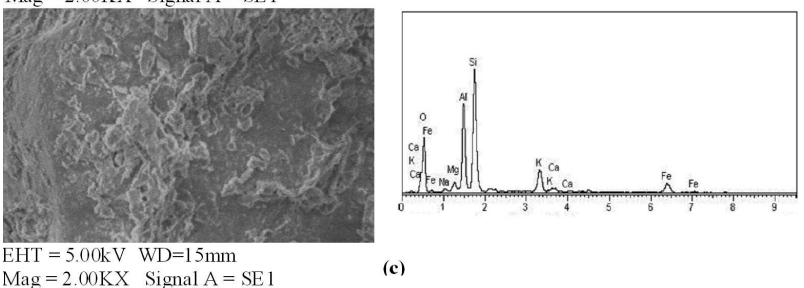

$\begin{array}{ll}\mathrm{Mag} & =2.00 \mathrm{KX} \quad \text { Signal } \mathrm{A}=\mathrm{SE}\end{array}$

(c)

Fig. 7. SEM-EDS micrographs of the fracture surfaces of clay materials of (a) SLM, (b) NKL, and (c) EDE +20 wt $\%$ reject sintered at $900{ }^{\circ} \mathrm{C}$, in the laboratory.

face of reformulated briquette specimens (raw clay material $+20 \mathrm{wt} \%$ reject sintered at $900{ }^{\circ} \mathrm{C}$ ) of SLM, NKL, and EDE are shown in Figs. 6 and 7. The sintered clay materials of SLM, NKL and EDE at $900{ }^{\circ} \mathrm{C}$ display large quartz grains (strong peak in the XRD) and a significant amount of porosity. On the contrary, reformulated briquette specimens of SLM, NKL, and EDE show clear signs of vitrification and a higher degree of closed porosity, resulting in the locking of marble and granite rejects in the pores of clay materials. The various elements observed in the EDS spectra are the constituents of the minerals obtained by XRD and XRF.

In the present work, one has initially studied the mechanical properties of industrially produced brick materials of SLM, NKL, and EDE in order to compare their results with the reformulated briquette specimens as a function of reject content and sintering temperature.

The flexural rupture strength is an important factor that can be used to assure the quality of recycled material as construction material. BS 6073 [10] requires $0.65 \mathrm{MPa}$ as a minimum flexural rupture strength for the building material to be used in structural applications. The sintering temperature effect of reformulated briquette specimen in the laboratory increases the flexural rupture strength through densification especially from 700 to $900{ }^{\circ} \mathrm{C}$. The reason for the gradual increase of flexural rupture strength of the reformulated briquette specimens of SLM, NKL, and EDE (Fig. 8) may be due to the presence of smaller particle size of granite and marble reject (silt fraction), acting as flux agent in the clay materials during the sintering process. Further, the reformulated briquette specimens tested for flexural rupture strength satisfy the requirement reported in literature [10] and indicates that granite and marble rejects can be incorporated in the raw clay materials of SLM, NKL, and EDE up to $50 \mathrm{wt} \%$ for producing clay bricks.

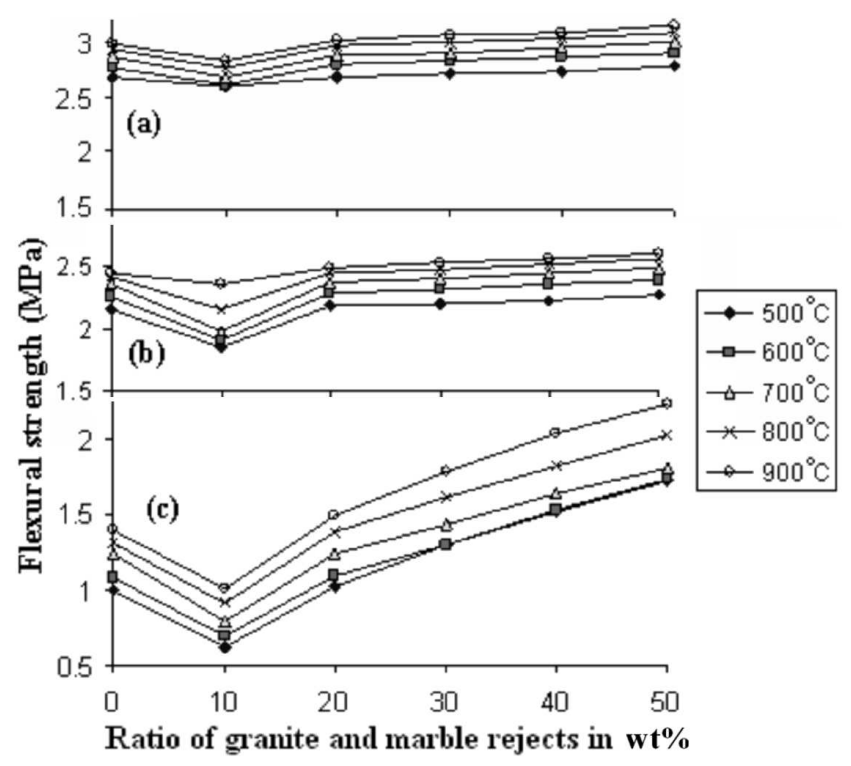

Fig. 8. Effect of reject content and sintering temperature on the flexural rupture strength of reformulated briquette specimens of (a) SLM, (b) NKL, and (c) EDE.

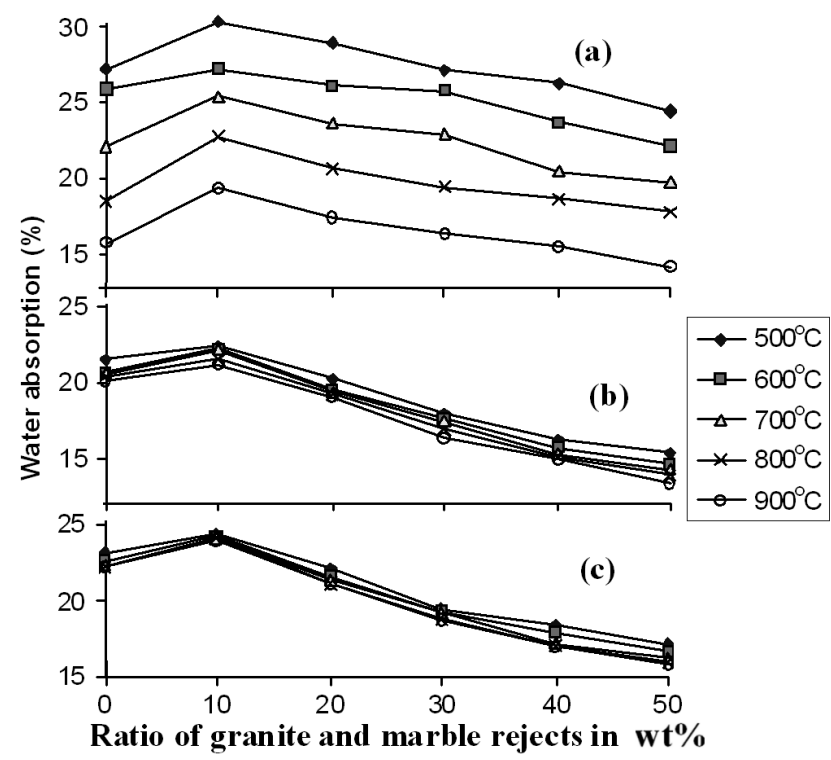

Fig. 9. Effect of reject content and sintering temperature on the water absorption of reformulated briquette specimens of (a) SLM, (b) NKL, and (c) EDE.

Water absorption, porosity and bulk density are effective parameters in evaluating the quality and densification of building brick. The water absorption is 


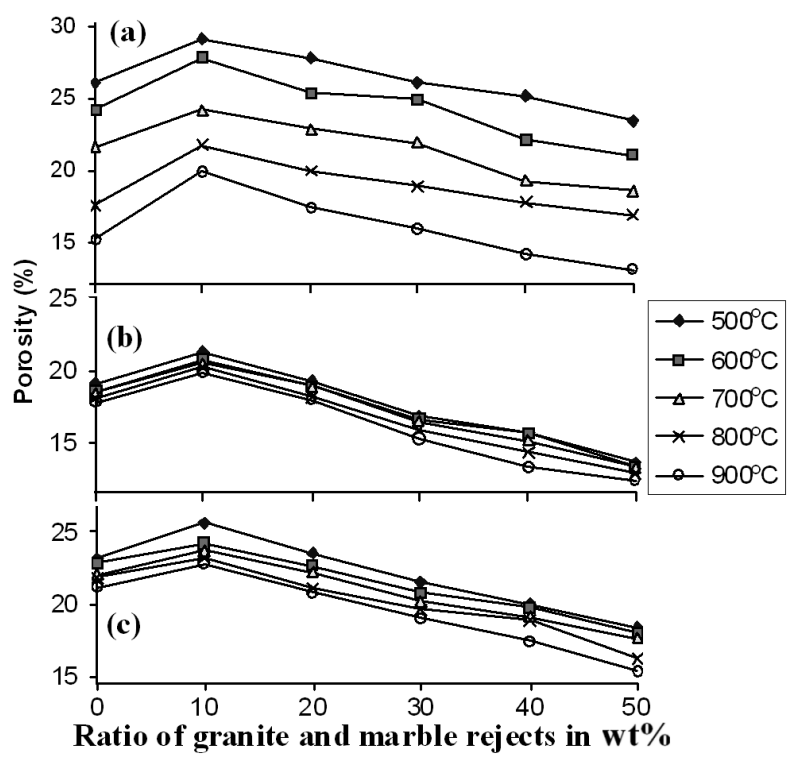

Fig. 10. Effect of reject content and sintering temperature on the porosity of reformulated briquette specimens of (a) SLM, (b) NKL, and (c) EDE.

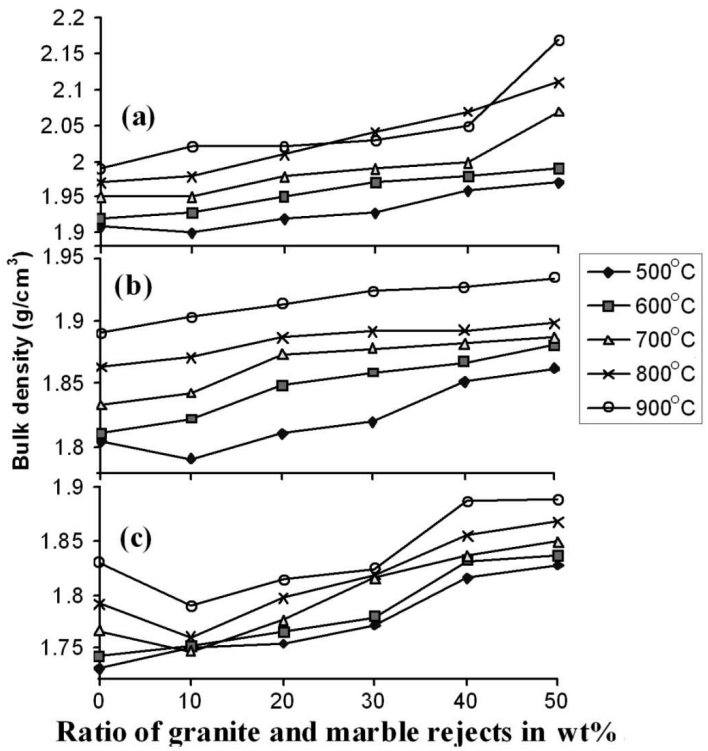

Fig. 11. Effect of reject content and sintering temperature on the bulk density of reformulated briquette specimens of (a) SLM, (b) NKL, and (c) EDE.

based on the amount of open pores in sintered specimens. Higher water absorption is an indication of a large number of open pores. This is also a function of flexural rupture strength and bulk density of the sintered specimen. According to results obtained (Figs. 9 and 10) the water absorption, porosity of reformulated briquette specimens of SLM, NKL, and EDE decrease significantly with increasing sintering temperature and reject content, whereas the bulk density of the above specimens increase with increasing sintering temperature and reject content (Fig. 11). Lin [22] has reported that the clay bricks normally have a bulk density of $1.8-2.0 \mathrm{~g} / \mathrm{cm}^{3}$. The bulk density tested for reformulated briquette specimens of SLM, NKL, and EDE sintered at different temperatures satisfy this requirement and indicate the suitability of recycling of granite and marble reject as raw material for the production of clay brick. The reason for decrease in water absorption and porosity and increase in bulk density are due to the pores of clay materials significantly locked by the incorporation of granite and marble reject at higher content, exhibiting better values at higher sintering temperature. The locking of reject in the pores is well established by scanning electron microscopy. Besides, the reformulated briquette specimens of SLM, NKL, and EDE obtained by the addition of rejects at higher contents and sintered at 800 and $900{ }^{\circ} \mathrm{C}$ exhibited better values of flexural rupture strength, water absorption, porosity and bulk density than the industrially produced clay bricks.

\section{Conclusion}

This work has demonstrated the effect of addition of marble and granite rejects as clay material substitute to produce the engineering quality of building brick. The proportion of reject in the clay material and the sintering temperature are the two key factors assuring the quality of bricks. Results obtained in this work show that reject content up to $50 \mathrm{wt} \%$ could be incorporated into the raw clay materials of SLM, NKL, and EDE in order to produce good quality bricks for building construction purposes. Further, the physical property studies record that the addition of marble and granite rejects into raw clay materials of SLM, NKL, and EDE imparts physical strength to the bricks when they are kilned at higher temperatures. More specifically, flexural rupture strength and bulk density are found to increase due to the addition of the above rejects. This is because of the fact that addition of the mineral matter especially quartz and feldspar to the clay material act as flux when they are kilned at higher temperature as evidenced by the physical test of the bricks. Finally, the incorporation of marble and granite rejects in clay brick production anticipates environmentally friendly recycling products, the solution for exhaustion of the natural resources and the conservation of not re-renewable resources.

\section{Acknowledgments}

Authors are thankful to Dr. Dipankar Das, Scientist, UGC-DAE Consortium for Scientific Research, Kolkata, India, for providing of the Mössbauer laboratory facility to carry out the above work. 


\section{References}

[1] R.R. Menezes, H.S. Ferreira, G.A. Neves, H. de L. Lira, H.C. Ferreira, J. Eur. Ceram. Soc. 25, 1149 (2005).

[2] Jr. F. Saboya, G.C. Xavier, J. Alexandre, Const. Build. Mater. 21, 1950 (2007).

[3] A.M. Segadaes, M.A. Carvalho, W. Acchar, Appl. Clay Sci. 30, 42 (2005).

[4] S. Dhanapandian, B. Gnanavel, Asian J. Appl. Sci. 2, 331 (2009).

[5] P. Torres, H.R. Fernandes, S. Agathopoulor, D.U. Tulyaganov, J.M.F. Ferreira, J. Eur. Ceram. Soc. 24, 3177 (2004).

[6] S. Dhanapandian, M. Shanthi, Pollut. Cont. 25, 145 (2009).

[7] P. Turgut, H.M. Algin, Build. Mater. 42, 3399 (2007).

[8] H.M. Algin, P. Turgut, Const. Build. Mater. 22, 1074 (2008).

[9] W. Acchar, F.A. Vieira, D. Hotza, Mater. Sci. Eng. 419, 306 (2006).

[10] BS 6073: Part I: Precast concrete masonry units. I. Specification for precast concrete masonry units, British Standards Institution, 1981.

[11] S.Kr. Das, K. Dana, N. Singh, R. Sarkar, Appl. Clay Sci. 29, 137 (2005).

[12] S.N. Monteiro, L.A. Pecanha, C.M.F. Vieira, J. Eur. Ceram. Soc. 24, 2349 (2004).
[13] U. Wagner, R. Gebhard, E. Murad, J. Riederer, I. Shimada, C. Ulberf, F.E. Wagner, MASCA Research $\mathrm{Pa}$ pers in Science and Archaeology, Supplement to, 1998, Vol. 15.

[14] U. Wagner, R. Gebhard, E. Murad, J. Riederer, I. Shimada, F.E Wagner, Archaeometry of Pre-Columbian Sites and Artifacts, Eds. D.A.Scott, P.Meyers, Institute of Archaeology and the Getty Conservation Institute, Los Angeles 1992, p. 67.

[15] C.M.F. Vieira, R. Sanchez, S.N. Monteiro, Const. Build. Mater. 22, 781 (2008).

[16] I. Demir, M. Baspinar, M. Orhan, Built. Environ. 40 , 1533 (2005).

[17] R. Venkatachalapathy, D. Gournis, C. Manoharan, S. Dhanapandian, K. Deenadayalan, Indian J. Pure Appl. Phys. 41, 833 (2003).

[18] U. Wagner, R. Gebhard, W. Hausler, T. Hutzelmann, J. Riederer, I. Shimada, J. Sosa, F.E. Wagner, Hyperfine Interact. 122, 163 (1999).

[19] Y. Hsia, Z. Hu, R. Liu, Hyperfine Interact. 41, 803 (1988).

[20] I. Maniatis, A. Simopoulos, A. Kostikar, Archaeological Ceramics, Smithsonian Institution Press, Washington (DC) 1982, p. 97.

[21] J.M.D. Coey, Atom. Energ. Rev. 18, 73 (1980).

[22] K.L. Lin, J. Hass. Mater. B 137, 1810 (2006). 